\title{
Impact of Foreign Direct Investment (FDI) on Entrepreneurship Development in Jiangsu Province - China
}

\author{
Michael Verner Menyah*1, Jincai Zhuang ${ }^{2}$, Evelyn Sappor ${ }^{3}$, Rejoice Akrashei ${ }^{4}$ \\ ${ }^{*}$ School of Management, Jiangsu University, Zhenjiang, Jiangsu, China. vernermenyah@yahoo.com \\ ${ }^{2}$ Institute of Rural studies, Jiangsu University, Zhenjiang, Jiangsu, China \\ ${ }^{3}$ Department of Engineering, Heriot-Watt University, Edinburgh, UK \\ ${ }^{4}$ Business School, University of Professional Studies, Accra, Ghana.
}

\begin{abstract}
Article Info

Volume 8, Issue 5

Page Number : 202-212

Publication Issue :

September-October-2021

Article History

Accepted : 20 Sep 2021

Published: 30 Sep 2021

Foreign Direct Investment (FDI) has served as a huge promoter of growth for many economies over the years, playing the role of supplementary income source for economies. The trend being identified now, however is that FDIs do come with adverse effect for host economies with one of the sector feeling the impact of the adverse impact being the local entrepreneurship.

This study therefore measured the severity of the adverse effect of FDIs on the economy of China whiles also evaluating the contribution of FDIs to the overall economy using Sequential Explanatory Design (SED). Using Statistical Package for Social Scientist (SPSS), the researchers conducted statistical analysis like t-test, Correlation, Multiple Regression Analysis, R-Square, Fstatistics and Variance Inflator Factors (VIF).

The findings of the study revealed that FDIs indeed have both positive and negative implications for the Chinese economy. The positive effects come in the form of inspiring innovation and infrastructural development, influx of investment capital and the liberalization of the economy form monopolies and unfair trading

The negative effect came in the form of stifling domestic entrepreneurship development as the foreign firms compete with local entrepreneurs for market, expertise, labor, capital and space for operation
\end{abstract}

Keywords: Foreign Direct Investment, SED, Jiangsu Province,

Entrepreneurship Development

\section{INTRODUCTION}

Foreign Direct Investment (FDI) has served as a huge promoter of growth for many economies over the years, playing the role of supplementary income source for economies. China is no exception to the above claim. As indicated in the 2020 United Nations

Conference on Trade and Development (UNCTD)World Investment Report, foreign direct investment directedinto the Chineseeconomy saw a

Copyright: (C) the author(s), publisher and licensee Technoscience Academy. This is an open-access article distributed under the terms of the Creative Commons Attribution Non-Commercial License, which permits unrestricted non-commercial use, distribution, and reproduction in any medium, provided the original work is properly cited 
tremendous increase from USD 138 billion in 2018 to USD 141 billion in 2019, (an indication of $+2 \%$ ). This growth was largely as a result of economic liberalization, accelerated increase in high-tech industries, and the flash increase in the formation of free trade zones. In 2019, the stock of FDI reached US $\$ 1,769$ billion, an exponential increase compared with US\$587 billion in 2010.China became the world's second principalbeneficiary of foreign direct investment nextto the United States and Singapore in 2019 and the largest beneficiary of aid in Asia. The execution of projects BASF (Germany), Exxon Mobil (USA) and automotive multinationals such as Tesla (USA), Toyota (Japan), Volkswagen and Daimler (both German) were cited to be the major FDIs over the period amidst the growth of production and capital investments. Although investmentinfluxes from the United States and Europe have waned considerably, capital investments from ASEAN countries saw a sustained upsurge with regional venturessurging from countries like Hong Kong, Singapore, Virgin Islands, South Korea, Cayman Islands, Japan, and Germany (Santandertrade.com, 2021).

A report by World Bank Doing Business in 2020 placedChina 31st out of 190 countries which a remarkable advancement compared to 2019 rating where China was placed 46th. This achievement put China among the top 10 economies with the utmostprogression in the 2019 and the 2020 reports. This advancementmirrors the progressionin a number of major economic growth indicatorsranging from improvement in business processes to improvements insustainable and reliable electricity supply and lessening of the bureaucracy in obtaining permits. China has alsodemonstrated high level of commitment to reform agenda aimed at improving the business monitoring environment. These reforms primarily targeted improving the proficiency of business processes in the form of trade tax cuts and lessening requirement for new investment entrants in to the Chinese economy.

In order to further entice foreign investment, apparatuses to progress the execution of major foreign investment projects like reduction in import taxes, streamlining customs and clearance processes, establishing virtual filing system and constant monitoring of foreign direct investment activities were implemented by the country. With enormous number of labor and investment experts being developed and churned out on regular bases, the country provided a source of low-cost production haven and thus making it a lucrative market for investors (Santandertrade.com, 2021). Foreign Direct Investments into China are mainly directed to the manufacturing, real estate, commercial and service leasing, computer services, wholesale and retail trade, financial intermediary, scientific research, transportation, energy and construction. This is a clear indication that FDI have a direct impact on domestic entrepreneurship development.

To many scholars,FDI reallyspawns both progressive and opposing externalities in entrepreneurial development. Scholars believe the positive FDI-based spillover of entrepreneurship is well linked todeveloping and transitional economies (Ayyagari and Kosová, 2010; Anwar and Sun, 2012; Apostolov, 2017) which goes to confirm the existence of adverse or reverse spillovers mostly in the short run in both developing and developed economies (De Backer \&Sleuwaegen, 2003; Albulescu and Tamasila, 2014;Albulescu and Tamasila, 2016;Apostolov, 2017; Danakol et al., 2017). The impact of spillover consequencesis much more evident when considering diverse FDI featureslike sources and format of FDI, and dispersiondevices among others. 


\section{Study Problem}

Modern models of entrepreneurship from the angle of economics hypothesized that institutional situations can facilitate or prevent entrepreneurial engagements which propels a country's economy (Baumol, 1990; Acs et al., 2008, 2009, 2013). Among these indicators is the level of FDI inflow into the economy and how those inflows are regulated. Scholars over the years have concentrated their attention on the positive repercussions of FDIs to economies, losing sight of the potential danger of stifling domestic industrialization and entrepreneurship development.

International entrepreneurship studies had limited attention to co-existent (institutional qualityintegrated) effects of diverseconstituents, including inflows and outflows, of FDI on entrepreneurial investments. The question then is "is FDI encouraging local entrepreneurship or it rather challenging its growth?" This is a big question that needed to be thoroughly explored.

\section{Purpose of the Study}

The objective of this study is to weigh both the positive and negative effects of FDI on domestic entrepreneurship. The study targeted the indigenous local entrepreneurship and contrast it against the waves of international investments. The study also looked at regulatory frameworks favoring increased FDI and ways of safeguarding local industrialization in spite of foreign inflows.

\section{Relevance}

This studyscrutinizes the consequence of foreign direct investment (FDI) on local entrepreneurial development. This study is very relevant because past studies were not definite as to whether or not FDIs necessarily nurtureentrepreneurship. It is however clear that FDI have positive tendencies on entrepreneurship in the nature of propagation of technology and technical know-how as well as negative tendencies like crowding out internal entrepreneurship. This study cleared this hoax hovering around the subject and set the pace for further studies.

\section{Literature Review}

\section{Introduction to Foreign Direct Investment}

Many politicians and scholars believed that foreign direct investment (FDI) holds significant constructivebearing on the development efforts of both donor and destination countries. Aside the provision of direct equity financing, FDIs also serve as a source of valuable technology and expertise recruitment as well as encouragingdirect connections with domestic businesses which in turns translates into an overall economic advancement. It is against this backdrop that both developed and developing countries encourageenticements to hearten foreign direct investment in their economies.

The efficacy of this special advantages of foreign direct investment hasbeen questioned owing to the various enticements that are provided to foreign companies in practice and their effect on the real GDP growth. What fuels this skeptism is largely due to empirical confirmation of the fact that the positive spillover impact of foreign direct investment in the host country is not in both micro and macro stages. Gorg and Greenwood (2002), when reviewing the micro-data on the secondary effects of foreign companies on domestic companies, established that these impacts are rather mostlydeleterious. Lipsey (2002) took a more satisfactoryon the subject matter and opined that there is proof of positive impacts.

Lipsey however observed an inconsistent relationship amongst the inflow of FDI or the scale of the flow and GDP and growth through an experimental macro research study. In addition, he believes that more 
attention needs to be paid to the different situations that hinder or promote the spread.

\section{Foreign Direct Investment and Entrepreneurship}

Menumo (2015) has indicated that generating and developing new business concepts is an important indicator of the entrepreneurial process. Many academic experiments have supported this assertion and empirically shown the positive impact of starting a new business on growth and development. Klapper et al. (2006) and Djankov et al. (2002) in their studies concluded that startup firmstend to be more proficient and the competitive burden they wield on other companies increases productivity and economic advancement. Early studies by Black and Strahan (2002) and Hause and Du Rietz (1984) also held the same conclusion that entrepreneurship has a positive impact on economic advancement. Further studies also showed that startups and young companies contribute to job opportunities than existing firms (Haltiwanger et al., 2010).

The feat of stimulating new businesses and domestic ventures is related to the enormous impact of foreign direct investment (FDI) by cosmopolitan corporations. This crowding effect is due to the dissemination of innovative technology and the transmission of new concepts and expertise through diverse mechanisms (Keller, 2004; Ayyagari and Kosova, 2010; and Danakol et al., 2013), including domestic companies as startups. Suppliers (backward contacts) or customers (forward contacts) entering foreign companies, especially in related vertical industries, are unlikely to be considered possiblecontestants of foreign companies. In addition to the above, another mechanism for the propagation of knowledge is through the experimentation effect, that is, new national companies can enter the same commerceby embracing practices comparable to those presented by foreign companies.

Another method that can be used for disseminating entrepreneurial skills of local is labor mobility where local entrepreneurs undergo facilitations from the foreign firms. With these exceptional expertise, workers can institute their own businesses when they are no longer in the employment of foreign companies. Finally, the fact that most expatriate businesses export their products is a determining factor to stimulating the entry of local companies by availingexport opportunities local entrepreneurs can use.

It is also identified in literature that the inflow of FDI can also have a crowding-out effect on entrepreneurshipif FDI indiscriminately competes with domestic producers and raises technical barriers to entry. This impact is likely to be horizontal in nature, because the threat of competition from national companies in the same industry is much greater. When foreign companies upsurge their average fixed overheads, entry barriers also ascend for domestic firms. Another way that foreign companies can squeeze out of local startups is to provide healthierworking conditions in the form of higher wages as compared to domestic competition. The resultant effect would be that most talented workers may end up working in foreign companies instead of using their expertise to build their own enterprises. Furthermore, foreign direct investment may not inspire other positive externalities, thus increasing the productivity of foreign companies or inspire new entrants.

Thus, the all-inclusive impact of multinational corporations on destination economy's entrepreneurship hinges on which of these two unparalleled forces dictates. It is also worth noting that the cumulative effect of FDI may ultimately hover on local circumstances that impact the absorptive capability of the host country (i.e. the ability utilize openings of the positive spill-over effects of FDI). In particular, the overall national regulatory environment for startups is considered among the most important local influencer. Busse and Groizard(2008) for instance found in their study that mostly countries with constrictingprincipleson FDI 
do not implore the ultimate advantages avail to countries in terms of the growth benefits of FDI, and regulations that affect the entry of firms in particular appear to be more important in achieving these expansion benefits. Although there is no strong evidence that bureaucratic business regulations will generate high entry costs and directly obstruct the formation of new businesses, bureaucracy is a limiting factor in FDI developments and needed to be paid much attention (Klapper et al., 2006). Therefore, any spillover of technology and expertise from FDI will crowd out domestic ventures and encourage the creation of infant businesses. Entry will not take place and the congestion effect of foreign direct investment will weaken

\section{Positive Effect of FDI on Entrepreneurship.}

Scholars have argued that by introducing technical knowledge of products and services that can be engrossed or copied by local companies, national business development is favored. This is considered an expertise diffusion or demonstration effect (Markusen and Venables, 1999). The positive duty of foreign direct investment in both developed and developing countries has been demonstrated directly linked to entrepreneurship (Görg and Strobl, 2002; Ayyagari and Kosová, 2010; Anwar and Sun, 2012; Apostolov, 2017).

Other avenues of business influence of FDI on entrepreneurship are related to labor spillovers (Meyer, 2004; Acs et al., 2007, 2009, 2013). Employees who are well trained in management and business practices may for instance leave a multinational company to open businesses for themselves. From a broader perspective, inbound FDI can serve as means of annexing expertise, technology and skills for knowledge-based business activities (Acs et al., 2013). This argument is supported by empirical evidence from developed and emerging economies (Acs et al., 2007, 2012).

These positive impact of the aforementioned foreign direct investment on entrepreneurship can be seen in the perspective of export business. As demonstrated by De Clercq et al. (2007) both incoming and outgoing FDI have a positive effect on the export orientation of entrepreneurs by urging domestic entrepreneurs to also use the decent transportation infrastructure created by foreign multinational companies as well as exploiting novelacquaintance about specific foreign markets obtained from foreign multinational companies to become international merchants or exporters whiles the outward FDI on the other hand leads to higher efficiency in the host country's economy and may compel entrepreneurs to provide higher quality products, thereby increasing their likelihood of success in the international market.

\section{Negative Effect of FDI on Entrepreneurship.}

The expansion of the international market of multinational companies can hamper national business activities. In fact, due to the intensification of competition in the infrastructure and capital market, the market power of multinational companies may replace that of domestic entrepreneurs (Grossman, 1984; Markusen and Venables, 1999; Görg and Strobl, 2002; De Backer and Sleuwaegen, 2003). The effect of market competition is particularly felt in lower product prices and / or higher average labor costs, which can displace unproductive local companies and inhibit probable entrepreneurs from starting novel enterprises.

Albulescu and Tamasila (2014) asserted that the inflow and outflow of FDI have opposite economic implications in different types of entrepreneurship, namely, Entrepreneurship Activity of Opportunity (OEA) and Necessary Entrepreneurship Activities (NEA). Further attention must be paid to the fact that there business spillovers based on FDI are diversified by differences in institutional structures (Acs et al., 2008, 2009; Meyer and Sinani, 2009; Danakol et al., 2017). Although there have been several attempts to completely resolve this relationship in emerging markets, mainly on incoming or net FDI (Herrera et al., 2014). 


\section{METHODS AND MATERIALS}

\section{Research design}

This study adopted Sequential Explanatory Design (SED) as cited in Hollstein, (2014). This type of design permits quantitative method to feed into the design of the qualitative method (Teddlie and Tashakkori, 2006) and thus, informed the decision of the study to adopt complementarity and triangulationmethods in a mixed approach nature for in-depth analysis of the cases gathered. The research design permitted the researcher to accord qualitative connotation to the cases under study so as to provide meaning and understanding to the statistical outcomes generated by the study.

\section{Population and Sampling Technique}

The population of the study was Five hundred (500) randomly selected startup firms in the Jiangsu Province of China. The sample was sparsely distributed over the agricultural, forestry and animal husbandry, mining, manufacturing, food processing, textile and leather works, metal industry, electrical, machinery and equipment, construction, transport, information technology (IT), hospitality, services and commerce industries.

The sample of the study was drawn from the population using simple random sampling so as to evade biases in selection of respondents. Five hundred (500) firms were selected using convenience sampling method. A 5-point Likert-type scale was developed following the work of Covin and Slevin 1990 cited in Etriya et al., 2012). Questionnaires were the main instrument of data collection for the study. The questionnaires were developed in Google Forms and sent to the emails of the respondents. Validity and reliability was achieved using face validity test and Cronbach alphatest respectively. Questions asked are directly interrelated with the objectives set out by the study. Descriptive statistics comprising mean scores and standard deviations and inferential statistical techniques conducted.
The study was descriptive in nature, elucidating the association between the various variables. Statistical Package for Social Scientist (SPSS) and Microsoft Excel were used to conduct both descriptive and inferential analysis. The descriptive statistics included mean, standard deviation, and graphical representation while the inferential analysis included t-test, Correlation, Multiple Regression Analysis, RSquare, F-statistics and Variance Inflator Factors (VIF).

\section{Model Development}

Several models have been developed over the years to link FDI and entrepreneurship but this study adopted the Knowledge Spillover Theory (KST) of Entrepreneurship extracted from Acs et al., (2007). Thisideology holds that spillovers of knowledge from foreign investors serve as entrepreneurship opportunities for individuals. The theory holds that this novel expertise (about products and processes) breedsconcepts for new products or complementary apparatuses that lead to new businesses. However, the background of entrepreneurial development (especially through the creation of a new company or new enterprises) is initiated by a country's economic setups. For example, countries with better property rights protection and due process traditions provide good conditions for fostering entrepreneurship.

For FDI, the technologies accompanying foreign investment are often new or advanced and provide new knowledge. This expertise then provide new prospects for local entrepreneurs, and in this case FDI will complement national entrepreneurship (creating knowledge spillovers that lead to start-ups). On the other hand, more "regular" FDI from foreign companies will replace domestic entrepreneurship, especially if the foreign investors are heftycorporations that make indigenous entrepreneurs just starting to feel the need to do so. The empirical evidence available on the effects of FDI on entrepreneurship is mixed (Da Backer and Sleuwaegen, 2003; and Liu et al., 2014).This simple 
model was employed to explore the positive and negative effect of FDI on local entrepreneurship.

\section{RESULTS AND DISCUSSIONS}

\section{Reliability and Validity}

Reliability is often used to determine internal steadiness of the research paradigm. A scale is said to have high internal consistency of reliability if the items of a scale measure comparable hypothesis (Robinson, 2009). Validity explicates the gradation to which a survey tool actually measures what it imports to measure (Fink, 2003). For reliability, the generally usedtool for internal consistency measure is the Cronbach's alpha coefficient.

The least acceptable internal consistency should have Cronbach's alpha coefficient of 0.7 (Hair et al., 2014). This form of measure also approximates the goodness of fit parameters of overall models. The most frequently used parameters for this valuation are Chisquare $(\chi 2)$, Degree of Freedom (df), Root Mean Square Error of Approximation (RMSEA), Normed Fit Index (), Comparative Fit Index (CFI) and Goodness Fit Index.

The above measures were employed and the following results were obtained $-\chi 2 / \mathrm{df}=1.81$, RMSEA $=0.57, \mathrm{NFI}=0.90, \mathrm{CFI}=0.93$, and GFI $=0.92$. The study found that the measurement model results portray a very good model fit, therefore the data is appropriate for advance analysis.

Table 4.1 Loading Factor

Item

(AVE=0.792 CR=0.823; $\mathrm{CA}=0.859$ )

FDI has greatly increased over the past .668 decade

Government policies are luring FDI into the country

Most FDI are set up in local areas .774

FDIs compete with local entrepreneurs for .826 market

FDIs compete with local entrepreneurs for .745 funds

FDIs promotes innovation and diversity in $\quad .737$ business

FDIs have increased governments fund .729 allocation for start ups

FDIs brings about technological .684 advancement

Source: Field work, 2021

\section{Descriptive Statistics}

This aspect of the study examined the mean analysis of the variables of the study. The respondents were of the view that FDI has greatly increased over the past decade $($ mean $=4.36 ; \mathrm{SD}=.583$ ). The respondents were of the view that Government policies are luring FDI into the country (mean $=3.86$; $\mathrm{SD}=.839$ ). The respondents were of the view that Most FDI are set up in local areas (mean $=3.49 ; \mathrm{SD}=.915)$. The respondents has indicated that FDIs compete with local entrepreneurs for market (mean $=4.55$; SD $=.528)$. The respondents has indicated that FDIs compete with local entrepreneurs for funds (mean = 3.94; SD = .775). The respondents were of the view that FDIs promotes innovation and diversity in business (mean $=4.16$; $\mathrm{SD}=.651$ ). The respondents were of the view that FDIs have increased Factor governments fund allocation for startups (mean = 3.79; Loadings SD $=.813)$. The respondents were of the view that FDIs brings about technological advancement (mean $=4.14 ; \mathrm{SD}=.706$ ). The study considered number of statements measuring each of the constructs with a Liker scale of 1 to 5 , with 1 being the least and 5 being the maximum. From the findings of the study, all the constructs have a mean score near or above 4 which indicate agreement to the statements. 
Table 4.2 Descriptive Statistics

\begin{tabular}{llllll}
\hline Item & N & Min & Max & Mean $\begin{array}{l}\text { Std. } \\
\text { Deviation }\end{array}$
\end{tabular}

FDI has greatly increased over the past decade

4.36

.583

Government policies are luring FDI into the country

100

1

5.36

Most FDI are set up in local areas

$100 \quad 1$

5

3.86

FDIs compete with local entrepreneurs for market

100

00

5

3.49

FDIs compete with local entrepreneurs for funds

100

1

5

4.55

.528

FDIs promotes innovation and diversity in business

100

100

1

5

3.94

.775

FDIs have increased governments fund allocation for start 100

1

5

4.16

.651 ups

FDIs brings about technological advancement

$100 \quad 1 \quad 5$

$4.14 \quad .706$

\section{Source: Field Survey (2021).}

This section of the study presents the correlation and regression analysis as well as test the hypothesis of the study.

Table 4.3 Correlation Analysis

\section{Correlations}

\begin{tabular}{llr|r} 
& & \multicolumn{1}{c|}{ FDI } & \multicolumn{1}{c}{ DE } \\
\hline \multirow{2}{*}{ FDI } & Pearson Correlation & 1 & $-.421^{*}$ \\
\cline { 2 - 4 } & Sig. (2-tailed) & & .000 \\
\cline { 2 - 4 } & $\mathrm{N}$ & 100 & 100 \\
\hline \multirow{2}{*}{ DE } & Pearson Correlation & $-.421^{* *}$ & 1 \\
\cline { 2 - 4 } & Sig. (2-tailed) & .000 & \\
\cline { 2 - 4 } & $\mathrm{N}$ & 100 & 100 \\
\hline
\end{tabular}

**. Correlation is significant at the 0.01 level (2tailed).
The correlation analysis indicate a negative relationship between Foreign Direct Investment (FDI) and domestic entrepreneurship $(r=-.421, p$ $<0.01)$. This indicates that FDI are in fact in competition with domestic entrepreneurs. There for the hypothesis that FDIs are directly competing with domestic entrepreneurs is supported.

Further, the study assess the extent at which FDI is affecting the operations of domestic entrepreneurs. The result of the regression analysis from table 4.5 indicated that, Foreign Direct Investment (FDI) has a significant 
negative effect on domestic entrepreneurship ( $\beta=$ $-.253, \mathrm{t}=3.164)$. Hence, an increase in Foreign Direct Investment (FDI) will result to a corresponding decrease of domestic entrepreneurship Therefore, thehypothesis
thatFDIs are crippling domestic entrepreneurshipis supported. Further, Foreign Direct Investment (FDI) explains up to $41 \%$ variance in domestic entrepreneurship.

Table 4.4 The Model Summary

Model Summary

\begin{tabular}{|l|r|r|r|r|}
\hline Model & R & R Square & Adjusted R Square & \multicolumn{1}{|c|}{$\begin{array}{c}\text { Std. Error of the } \\
\text { Estimate }\end{array}$} \\
\hline 1 & $.573^{\mathrm{a}}$ & .409 & .213 & 1.678 \\
\hline
\end{tabular}

a. Predictors: (Constant), FDI

b. Domestic entrepreneurship

Source: Field Survey (2021).

Table 4.5 Coefficients of Regression Model.

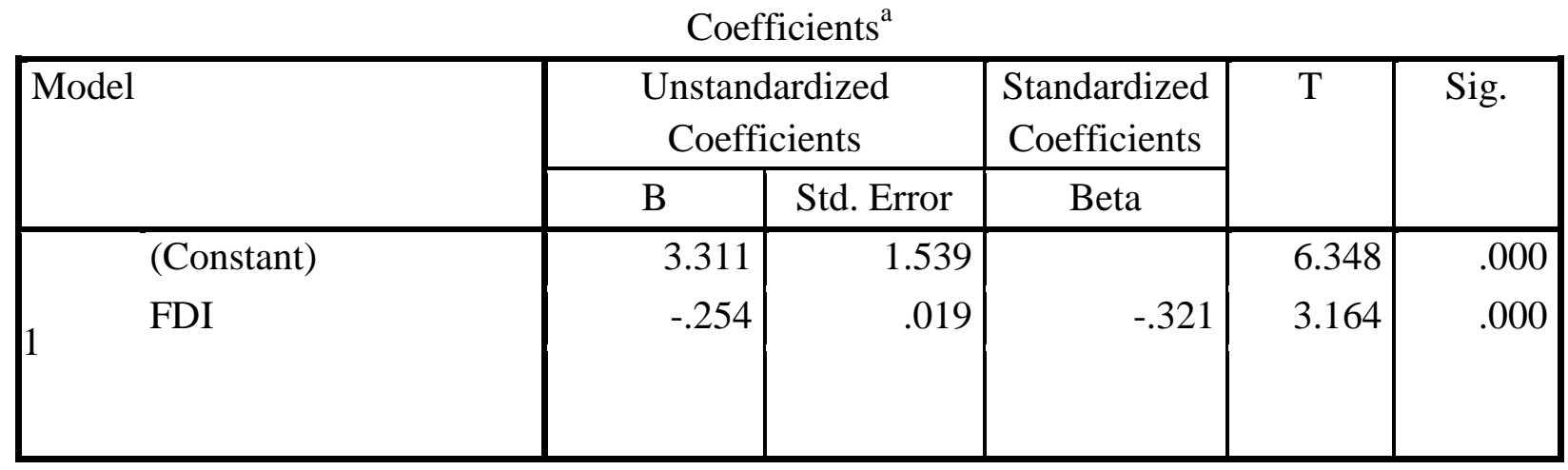

a. Dependent Variable: Domestic entrepreneurship

\section{Source: Field Survey (2021)}

\section{CONCLUSION}

The study revealed thought provoking insights in Foreign direct investments and its effect on the Chinese economy. It was seen that the easing of regulations on foreign investment by the government has been the major cost of inflow of investors. This was complemented by favorable operational conditions in the country.

The influx of foreign investors however do not come without challenges. The study realized that FDI has led to challenges like competing with local businesses for market, funds, skilled labour, raw materials and capital. This, the study has revealed has stifled the growth of domestic startup businesses.

The good news however is that FDIs are accompanied with the promotion of innovation and diversity in doing business, has forced the government to increased allocation for startups and also led to technological advancement.

The study therefore conclude that despite the seemingly good imports of FDIs to any economy, there are negative implications that needed to be tackled squarely so as to have a balanced impact on the economy as whole. Measures must be taken to regulate the policies of fair trade, and corporate 
ethics so as to protect domestic businesses without the financial muscle against unfair competition.

\section{REFERENCES}

[1]. Acs, Z.J., Audretsch, D. B. \& Lehmann, E. E. (2013). The Knowledge Spillover Theory of Entrepreneurship. Small Business Economics, Vol. 41 No. 4, pp. 757-774.

[2]. Acs, Z., Desai, S. and Hessels, J. (2008). Entrepreneurship, Economic Development and Institutions. Small Business Economics, 31 (3), 219-234.

[3]. Aitken, B. J. and A. Harrison. 1999. "Do Domestic Firms Benefit from Direct Foreign Investment? Evidence from Venezuela." American Economic Review 89: 605-618.

[4]. Albulescu, C.T. \&Tamasila, M. (2016). Exploring the Role of FDI in Enhancing the Entrepreneurial Activity in Europe: A Panel Data Analysis.International Entrepreneurship and Management Journal, Vol. 12 No. 3, pp. 629-657.

[5]. Anwar, S. and Sun, S. (2012). FDI and Market Entry/Exit: Evidence from China. Journal of Asian Economics, Vol. 23 No. 5, pp. 487-498.

[6]. Ayyagari, M. and Kosova, R. (2010). Does FDI facilitate domestic entry? Evidence from the Czech Republic. Review of International Economics, 18 (1), 14-29.

[7]. Ayyagari, M., \&Kosová, R. (2006). Does FDI Facilitate Domestic Entrepreneurship? Evidence from the Czech Republic. Working paper.

[8]. Baumol, W. (1990). Entrepreneurship: Productive, Unproductive, and Destructive. Journal of Political Economy, 98 (5), 893-921.

[9]. Black, S and P. Strahan (2002). Entrepreneurship and Bank Credit Availability. Journal of Finance Danakol, S, Estrin, S. Reynolds, \&Weitzel U. (2013). Foreign Direct Investment and Domestic Entrepreneurship:
Blessing or Curse? IZA Discussion Paper N0. 7796.57, 2807-33.

[10]. Busse, M. \&Groizard, J. (2008). Foreign Direct Investment, Regulations and Growth. The

[11]. China Statistical Yearbook (2019) China: Foreign Investment. Retrieved from https://santandertrade.com/en/portal/establishoverseas/china/foreign-investment (8th August, 2021)

[12]. Covin, J. G., and Slevein, D. P. (1986).The Development and Testing Of an Organizational-Level Entrepreneurship Scale. In Frontiers of Entrepreneurship Research. Wellesley, MA: Babson College, 628-639.

[13]. De Backer, K. \&Sleuwaegen, L. (2003). Does Foreign Direct Investment Crowd Out Domestic Entrepreneurship?Review of Industrial Organization, Vol. 22 No. 1, pp. 6784.

[14]. De Backer, K. and Sleuwaegen, L. (2003). Does Foreign Direct Investment Crowd Out Domestic Entrepreneurship? Review of Industrial Organization, 22 (1), 67-84.

[15]. De Clercq, D., Hessels, J. \& Van Stel, A. (2007). Knowledge Spillovers through FDI and Trade and Entrepreneurs' Export Orientation. Paper presented at the Academy of Management Proceedings, Philadelphia, PA.

[16]. Djankov, S, Ganser, T.,McLiesh, C., Ramalho, \&Shleifer A. (2010). The Effect of Corporate Taxes on Investment and Entrepreneurship. American Economic Journal: Macroeconomics 2, 31-64.

[17]. Djankov, S., La Porta, R. Lopez-de Silanes, F. and Shleifer, A. (2002). The Regulation of Entry. Quarterly Journal of Economics, 117 (1), 1-37.

[18]. Gorg, H. and Strobl, E. (2002). Multinational Companies and Indigenous Development: An Empirical Analysis. European Economic Review, 46 (7), 1305-1322. 
[19]. Grossman, G. M. (1984). International Trade, Foreign Investment, and the Formation of the Entrepreneurial Class. American Economic Review, 74 (4), 605-614.

[20]. Haltiwanger, J.,Jarmin, R.\&Miranda, J. (2010). Who Create Jobs? Small vs. Large vs. Young.US Census Bureau CES Research Paper 10-7.

[21]. Hause, J. \&Du Rietz G. (1984). Entry, Industry Growth, and the Micro Dynamics of Industry Supply. Journal of Political Economy 92, 73357.

[22]. Herrera-Echeverri, H., Haar, J. \&EstévezBretón, J. B. (2014). Foreign Direct Investment, Institutional Quality, Economic Freedom and Entrepreneurship in Emerging Markets. Journal of Business Research, Vol. 67 No. 9, pp. 19211932.

[23]. Holstein, B. (2014). Mixed Methods Social Networks Research:(An introduction. In S. Dominguez \& B. Hollstein (Eds.) Mixed Methods Social Networks Research: Design and Applications, 1, 3-35.

[24]. Klapper, L.,Laeven, L.\&Rajan R. (2006). Entry Regulation as a Barrier to Entrepreneurship. Journal of Financial Economics 82, 591-629.

[25]. Lipsey, R. E. 2002. "Home and Host Country Effects of FDI." NBER Working Paper 9293.

[26]. Markusen, J. R. and Venables, A. J. (1999). Foreign Direct Investment as a Catalyst for Industrial Development.European Economic Review, 43 (2), 335-356.

[27]. Meyer, K. E. \&Sinani, E. (2009). When And Where Does Foreign Direct Investment Generate Positive Spillovers? A MetaAnalysis.Journal of International Business Studies, Vol. 40 No. 7,pp. 1075-1094.

[28]. Munemo, J. (2012). Entrepreneurship in Developing Countries: Is Africa Different? Journal of Developmental Entrepreneurship 17, 1-12.

[29]. Teddlie, C \&Tashakkori, A. (2003). Major Issues and Controversies in the Use of Mixed Methods in the Social and Behavioural Sciences(In Tashakkori, A. And Teddlie, C (Eds) Handbook of Mixed Methods in the Social and Behavioural Research). Thousand Oaks, CA: Sage, pp. 3-50.

[30]. UNCTAD (2013). World Investment Report. Retrieved from http://unctad.org/en/publicationslibrary/wir201 3_en.pdf [31]. World Economy 31, 861-886.

\section{Cite this article as :}

Michael Verner Menyah, Jincai Zhuang, Evelyn Sappor, Rejoice Akrashei, "Impact of Foreign Direct Investment (FDI) on Entrepreneurship Development in Jiangsu Province - China", International Journal of Scientific Research in Science, Engineering and Technology (IJSRSET), Online ISSN : 2394-4099, Print ISSN : 2395-1990, Volume 8 Issue 5, pp. 202-212, September-October 2021. Available at doi : https://doi.org/10.32628/IJSRSET218524 Journal URL : https://ijsrset.com/IJSRSET218524 